\title{
ALKYLATION OF CYANOACETIC ESTER.
}

By John C. Hessler.

Received June 4, 1913.

In a study of alkyl malonic nitriles, carried out some years ago, ${ }^{1}$ the writer found that the Conrad-Limpach reaction, which was used for the preparation of ethylcyanoacetic ester, gave a mixture containing about $30 \%$ of diethylcyanoacetic ester. In this experiment ethyl iodide was used as the alkylating material. Recent experiments by Hadley, ${ }^{2}$ carried out under the writer's direction, show that when ethyl bromide is used, practically the same amount $(28 \%)$ of diethylcyanoacetic ester is formed. The present paper describes the results obtained in the alkylation of cyanoacetic ester by means of methyl, isopropyl, and isoamyl iodides. The investigation is being extended to include the alkylation of several esters of cyanoacetic acid and the use, as solvents, of other alcohols than ethyl alcohol, especially methyl and isoamyl alcohols.

\section{Experimental.}

Derivatives of Methylcyanoacetic Ester.

(a) Preparation of the Crude Ester.-The method was that of Henry: ${ }^{3}$ 20 grams of cyanoacetic ester, dissolved in 80 grams of absolute alcohol, were treated with 4.07 grams of sodium, also dissolved in 80 grams of absolute alcohol, and to the resulting sodium salt there was added a slight excess (26.2 grams) of methyl iodide. The mixture became hot, and was cooled with running water. It was neutral to litmus in five minutes. The alcohol was then distilled off, water was added, and the product was extracted with ether. The ether was dried with calcium chloride. When the ether solution was fractionated, there were obtained 17.1 grams of a fragrant liquid boiling at $87^{\circ}-90^{\circ}$ under $12 \mathrm{~mm}$. This is $72 \%$ of the theoretical amount.

(b) Dimethylcyanoacetic Ester.--The crude ester obtained in the methylation of cyanoacetic ester was shaken four times, in ether solution, with I0 \% sodium hydroxide solution, and the ether solution was dried with calcium chloride. When it was fractionated, it gave 2.I grams, $i$. $e_{\text {. }}$, $12.3 \%$, of dimethylcyanoacetic ester. This is a colorless, ethereal liquid boiling at $77^{\circ}$ under $9 \mathrm{~mm}$., and at $185^{\circ}$ under ordinary pressure.

An analysis gave the following result:

$$
\begin{array}{ll}
\text { Calculated for } \mathrm{C}_{7} \mathrm{H}_{11} \mathrm{NO}_{2}: & \text { C, } 59.57 ; \mathrm{H}, 7.80 \\
\text { Found: } & \text { C, } 59.63 ; \mathrm{H}, 7.75
\end{array}
$$

Dimethylcyanoacetic ester is dissolved by concentrated ammonia water in 40 hours, and by 10\% sodium hydroxide in 20 minutes. Its specific gravity is 0.971 at $26^{\circ}$.

${ }^{1}$ Am. Chem. J., 22, 160.

$=$ ThIS JoURNAL, 34, 923 .

${ }^{3}$ Jahresber., 1889, 637; Belg. Acad. Bull., [3] 18,670. 
(c) Methylcyanoacetic Acid and its Silver Salt.-The sodium hydroxide solution obtained in $(b)$ was acidified with dilute sulfuric acid and extracted with ether. The ether solution was dried with calcium chloride and then fractionated. There were obtained 8.2 grams of methylcyanoacetic acid, a thick, colorless liquid boiling without decomposition at I $42^{\circ}-145^{\circ}$ under I I mm. pressure. Its specific gravity was $\mathrm{I} .14$ at $20^{\circ} \mathrm{C}$.

The acid was converted into the silver salt by treating its water solution with ammonia water until it was slightly alkaline, and then adding a small excess of a concentrated solution of silver nitrate. The silver salt crystallized out in almost theoretical amount as hard, white granules. An analysis, by ignition, gave the following result:

Calculated for $\mathrm{C}_{4} \mathrm{H}_{4} \mathrm{NO}_{2} \mathrm{Ag}$ : Ag, 52.43 ; found: $\mathrm{Ag}, 52,23$.

(d) Pure Methylcyanoacetic Ester. -The silver salt of methylcyanoacetic acid was treated with twice the theoretical amount of ethyl iodide and left for two days. Ether was then added, the silver iodide was filtered off, and the ether was distilled. The methylcyanoacetic ester was formed in theoretical amount. It boiled at $89^{\circ}-90^{\circ} \mathrm{C}$. under $20 \mathrm{~mm}$. pressure, and at $192^{\circ}-193^{\circ}$ under ordinary pressure. Its specific gravity was 0.998 at $22^{\circ}$.

\section{Derivatives of Isopropylcyanoacetic Ester.}

(a) Preparation of Di-isopropylcyanoacetic Ester.-Crude isopropylcyanoacetic ester was made in the same way as methylcyanoacetic ester, after the method of Henry. ${ }^{1}$ Twenty-two grams were obtained from 25 grams of cyanoacetic ester. The product boiled at $107^{\circ}-120^{\circ}$ under I9 $\mathrm{mm}$. pressure. It was shaken with $10 \%$ sodium hydroxide solution (no ether) at intervals for an hour. The unchanged ester was then extracted with ether. The di-isopropylcyanoacetic ester obtained weighed 2 grams, boiled at $240^{\circ}$, and had a specific gravity of 0.918 at $29.4^{\circ}$. An analysis gave the following result:

Calculated for $\mathrm{C}_{13} \mathrm{H}_{19} \mathrm{O}_{2} \mathrm{~N}: \mathrm{N}, 7 . \mathrm{II}$; found: $\mathrm{N}, 7.53$.

(b) Isopropylcyanoacetic Acid ( $\alpha$-Cyanoisovalerianic Acid).-The sodium hydroxide solution obtained in (a) was acidified with dilute sulfuric acid and extracted with ether. When the dried ether solution was distilled, it gave 14 grams of isopropylcyanoacetic acid boiling at $166^{\circ}-168^{\circ} \mathrm{C}$. under $28 \mathrm{~mm}$. The acid is slightly decomposed in the distillation, and has the odor of valeronitrile.

The silver salt was made in the usual way: the aqueous solution of the acid was treated with a small excess of ammonia water, and the resulting solution was left for Io hours in vacuo over sulfuric acid. It was then filtered and treated with a slight excess of concentrated silver nitrate solution. The silver salt was precipitated as a snow-white solid. Almost the calculated amount was obtained. An analysis resulted as follows:

\footnotetext{
1 Jahreşber., $1889,637$.
} 
Calculated for $\mathrm{C}_{0} \mathrm{H}_{8} \mathrm{O}_{2} \mathrm{NAg}$ : $\mathrm{Ag}, 46.15$; found: $\mathrm{Ag}, 46.01$.

(c) Isopropylcyanoacetic Ester.-The silver salt of isopropylcyanoacetic acid was treated with twice the theoretical amount of ethyl iodide. The mixture became so hot that the ethyl iodide boiled, When the reaction was over, ether was added, the silver iodide was filtered off, and the solution was distilled. From 21 grams of silver salt 12.7 grams of the ester were obtained. Calculated amount, I3.9 grams. The ester boiled at $113^{\circ}$ under $25 \mathrm{~mm}$., and at $2 \mathrm{II}^{\circ}$ under $739 \mathrm{~mm}$, and had a specific gravity of 0.962 at $29.2^{\circ}$. These figures agree very closely with those of Henry. An analysis gave the following result:

$$
\begin{aligned}
& \text { Calculated for } \mathrm{C}_{8} \mathrm{H}_{13} \mathrm{O}_{2} \mathrm{~N}: \mathrm{C}, 6 \mathrm{I} .94 ; \mathrm{H}, 8.39 \\
& \text { Found: } \\
& \text { C, } 61.99 ; \mathrm{H}, 8.67
\end{aligned}
$$

\section{Derivatives of Isoamylcyanoacetic Ester.}

(a) Preparation of Isoamylcyanoacetic Ester.-To prepare the ester 4. I grams of sodium in 80 grams of absolute alcohol were added to 20 grams of cyanoacetic ester dissolved in 80 grams of absolute alcohol, and, as the sodium salt began to separate out, 37 grams (a slight excess) of isoamyl iodide were added. The mixture became warm. It was heated for two hours under a reflux condenser, and the alcohol was then distilled off on an oil bath until the outside temperature was $170^{\circ}$. Water was then added to the residue, and the reaction product was extracted with ether. The ether solution was washed with water, dried with calcium chloride, and distilled. The residue was distilled under $15 \mathrm{~mm}$., and gave the following fractions:

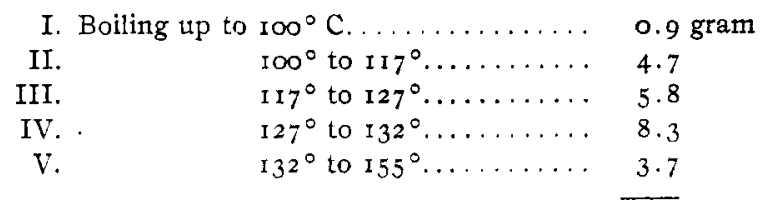

Total.....

234 grams

Some tar remained in the distilling flask. Fractions II to $\mathrm{V}$ were refractionated twice in vacuo, and there was obtained a colorless liquid

\begin{tabular}{|c|}
\hline $\mathrm{H}_{17} \mathrm{O}_{2} \mathrm{~N}$ \\
\hline Found (I) \\
\hline Found (II; see below): \\
\hline
\end{tabular}
boiling at $126^{\circ}-\mathrm{I} 27^{\circ}$ under I I mm. pressure. This was isoamylcyanoacetic ester, as shown by the following analysis:

The pure ester was prepared from the silver salt of isoamylcyanoacetic acid $(q . v$.$) . It boiled at 125^{\circ}$ under $\mathrm{I} 2 \mathrm{~mm}$., and at $24^{\circ} 1^{\circ}$ under $749 \mathrm{~mm}$. Its specific gravity was 0.939 at $2 \mathrm{I}^{\circ} \mathrm{C}$. Analysis II (above) gives the figures obtained for the ester prepared from the silver salt. Isoamylcyanoacetic ester is saponified by $10 \%$ sodium hydroxide, giving the 
sodium salt of isoamylcyanoacetic acid. Concentrated ammonia water converts it into the acid amide.

(b) Di-isoamylcyanoacetic Ester.-The higher-boiling fractions of the crude isoamylcyanoacetic ester consist largely of the di-isoamyl ester. To determin its amount the whole of a second preparation (22.7 grams, excluding a small forerunner) was treated for half an hour with 10\% sodium hydroxide solution. Heat was given off, and most of the liquid ester disappeared. The di-isoamyl ester was extracted with ether, and the ether solution was dried with calcium chloride and fractionated. Yield, 6.4 grams, boiling at $158^{\circ}-159^{\circ}$ under $16 \mathrm{~mm}$. pressure. Its specific gravity was 0.909 at $22^{\circ}$. The di-isoamyl ester is thus $28 \%$ of the original reaction product. An analysis resulted as follows:

$$
\begin{aligned}
& \text { Calculated for } \mathrm{C}_{13} \mathrm{H}_{27} \mathrm{O}_{2} \mathrm{~N}: \mathrm{C}, 7 \text { ז.15; H, } 10.67 \\
& \text { Found: } \\
& \text { C, } 70.50 ; \mathrm{H}, 10.64
\end{aligned}
$$

Di-isoamylcyanoacetic ester was not affected by long standing with cold 10\% sodium hydroxide, nor by concentrated ammonia water. It showed no tendency to become solid.

(c) Isoamylcyanoacetic Acid.--The acid was obtained by acidifying the sodium hydroxide solution of (b) and extracting it with ether. When the ether solution was dried with calcium chloride, and distilled, it yielded I I.9 grams of isoamylcyanoacetic acid. This boiled at $175^{\circ}-180^{\circ}$ under I $6 \mathrm{~mm}$. pressure, but was slightly decomposed, with evolution of carbon dioxide. The distilled acid was dissolved in ether, and extracted with sodium carbonate solution. The sodium carbonate solution was acidified, extracted, etc., and the acid was obtained as a colorless liquid which solidified to a white, snow-like solid. This melted at $47^{\circ}-48^{\circ}$, and had an odor like that of valerianic acid.

The isoamylcyanoacetic acid obtained was converted into its ammonium salt, and this was treated with a small excess of silver nitrate in concentrated aqueous solution. The silver salt came down as a white precipitate, which was curdy at first but soon changed to a crystallin powder. Yield, $87 \%$ of the theoretical. An analysis was made by ignition:

Calculated for $\mathrm{C}_{8} \mathrm{H}_{12} \mathrm{NO}_{2} \mathrm{Ag}: \mathrm{Ag}, 4 \mathrm{I} .22$; found: $\mathrm{Ag}, 40.99$.

The silver salt is stable, except in direct sunlight, which darkens it. Ethyl iodide converts it into its ethyl ester, as before stated.

(d) Isoamylcyanoacetamide. - To get the amide, the mixture of monoand di-isoamylcyanoacetic ester, boiling above II $5^{\circ}$ under $15 \mathrm{~mm}$. was treated with an excess of concentrated ammonia water and allowed to stand for several hours. A mass of white crystals separated out. When crystallized from alcohol, the amide melted at $142^{\circ}$. Guareschi ${ }^{1}$ gives the melting point as $142.5^{\circ} \mathrm{C}$. An analysis gave the following result:

1 Atti R. Accad. Torino, 37; Ann., 325, 205. 


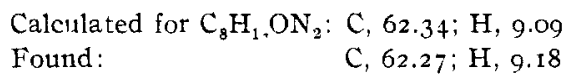

(e) Isoamylmalononitrile.-The nitrile was prepared from isoamylcyanoacetamide (I I.5 grams) and phosphorus pentachloride (5.4 grams). These substances were mixed in an Anschütz flask and heated in vacuo, in a metal bath at $120^{\circ}-130^{\circ}$, to start the reaction. When the reaction was practically over, the nitrile was distilled off as a colorless liquid boiling it about $120^{\circ}$ under $17 \mathrm{~mm}$. The crude product weighed 7.5 grams, or $14 \%$ of the theoretical amount. It was shaken with water and soda olution to remove hydrogen chloride and phosphorus oxychloride, and hen extracted with ether. The ether solution was dried with calcium hloride. When the ether was distilled, there remained 6.8 grams of nitrile oriling at $121^{\circ}-122^{\circ}$ under $18 \mathrm{~mm}$. Its specific gravity was 0.899 at $25^{\circ}$. An analysis resulted as follows:

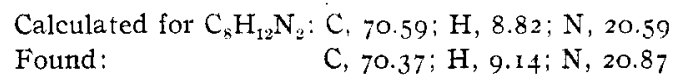

James Millikin University, Decatur, Ilz.

[CONTRIBUtIONS HROM THE SHEFFIELd IAABORATORY OF YALE UNIVERSITY.]

\section{RESEARCHES ON PYRIMIDINES. LXIII. A NEW METHOD OF SYNTHESIZING URAMILS AND THIOURAMILS.}

By Treat B. Johnson and Norman A. Sherard.

Received June 10, 1913.

Under the term uramil we include in this work only pyrimidines which contain the nucleus (I). The imido derivatives are not considered. Two types of mono thiouramils are theoretically possible, one, in which the sulfur atom has displaced oxygen in position 2 of the pyrimidine ring (II), and the other, where sulfur occupies position 4 or 6 of the ring (III). Two dithiouramils are also possible, IV and $\mathrm{V}$. If we disregard the imido derivatives of 2 -thiouramil, which have been prepared by Traube, ${ }^{1}$ the only thiouramils which have been described in the literature are 4-thiouramil and 1,3-dimethyl-4-thiouramil. The former was prepared independently by Weidel and Niemilowicz ${ }^{2}$ and Fischer and Ach, ${ }^{3}$ by heating uric acid with ammonium hydrogen sulfide. This thiouramil can be converted into uramil by oxidation with bromine. Fischer and Ach $^{4}$ prepared I,3-dimethyl-4-thiouramil by the interaction of ammonium hydrogen sulfide with I,3-dimethyluric acid. The methylether of 2-thiouramil has been prepared by Wheeler and Jamieson ${ }^{5}$ and the corresponding

1 Ann., 331, 80.

${ }^{2}$ Monats., 16, 729.

${ }^{3}$ Ann., 288, 57.

Loc. cit.

s. Am. Chem. J, 32, $35 \mathrm{I}$. 